\title{
Sodium Channel Protein Type 2 Subunit Alpha
}

National Cancer Institute

\section{Source}

National Cancer Institute. Sodium Channel Protein Type 2 Subunit Alpha. NCI Thesaurus.

Code C102446.

Sodium channel protein type 2 subunit alpha (2005 aa, $228 \mathrm{kDa}$ ) is encoded by the human SCN2A gene. This protein is involved in membrane polarization. 